\title{
Editorial: New developments in the law and what these mean for your brand protection strategy
}

A strong brand is hugely valuable it embodies the brand owner's entire investment in its product, from the development time and resources, to the marketing and publicity and the goodwill generated by the success of the product. How else do people make sure they have the product they want, other than by the brand name? This is true whether the product is biscuits, sophisticated software or management consulting services. Brand owners are becoming more and more sophisticated in understanding the degree to which brands carry the value of the business.

This edition of the Journal of Brand Management looks, therefore, at the practical aspects of choosing and maintaining a brand in today's legal framework. Before adopting a brand it is important to understand whether the brand is going to be protectable and enforceable; in commercial terms, whether it will stand out from the crowd as an identifier of the business.

\section{CHOOSING THE BRAND}

There have been a number of developments in the law; in particular the decision in the Baby-Dry case (discussed in 'Legal pitfalls in protecting advertising slogans in the European Union'), which has broadened the range of descriptive marks for which brand owners can obtain protection. Descriptive marks are, for obvious reasons, attractive to marketers, and there has long been a tension between the desire to use these marks and their vulnerability in terms of protection and enforcement. A short update is given on the recent developments in design rights discussed in 'Using other intellectual property rights to enhance brand value' which provide the brand owner with new tools in the armoury of protection. These new rights may permit the protection of stylish slogans which are not otherwise protectable as trade marks.

As a contrast to the Baby-Dry case, the decision in the Arsenal case - an interesting case regarding use of the Arsenal football club trade mark and $\operatorname{logo}$ - is considered in 'Round-up of the Arsenal case and its impact'. The decision in the Arsenal case questions the usefulness of descriptive marks.

In the paper 'Building strong brands', a practical look is taken at steps which can be taken before a mark is chosen to check that the mark is available and protectable. This paper also looks at ways in which, once the mark has been chosen, it can be maintained so that it grows in strength and becomes more distinctive in a crowded marketplace.

'Image rights - Are they worth the contract they're written on?' takes a special look at an area which is of particular interest because of the amounts of money involved. Take, for example, the power of the David Beckham name and image, or Elvis Presley. The English law does not recognise 
personality and image rights as such, which creates an extraordinary lacuna given the importance of these rights. There are, however, steps which can be taken to protect them.

\section{ONGOING PROTECTION AND THE CRIMINAL ELEMENT}

Once brands are up and running, and protected through registration, common law rights or a combination of the two, care needs to be taken not to infringe the brand owner's rights. A common area of controversy is that of advertising. Advertisers often wish to refer to a competing brand in order to state that their biscuits are tastier or that their batteries last longer. A number of well-known cases have considered the extent to which advertisers are permitted to make these references before they are considered to infringe the brand owner's rights. Generally, it has been difficult for brand owners to prevent comparisons by other advertisers. The paper 'New European Union directive to curb unfair and misleading commercial practices' considers the new directive and resulting regulation which will, among other things, prohibit unfair commercial practices and, in particular, impose requirements on advertisers which are likely to be more stringent than the current limitations on the use of trade marks.

Another important consideration for brand owners is, of course, enforcement. The criminal aspects of infringement, from online piracy to counterfeiting and the increasingly sophisticated methods employed by counterfeiters and music pirates are considered in two papers: 'Online piracy of recorded music' and
'Counterfeiting: Tricks and trends'. The practical steps being taken by rights owners to deter counterfeiters are examined. These measures include the use of holograms, invisible ink and radio tagging. The recent formation of the Global Business Leaders Alliance against Counterfeiting (GBLAAC) is an important development. The alliance - which includes some of the world's most influential multi-national companies — will press for government action to prevent counterfeiting. It is hoped that counterfeiting will become an important item on the political agenda, because counterfeiting is not only damaging to brand owners, but is also linked to organised crime, drugs and moneylaundering.

Having identified piracy or counterfeiting, the brand owner's rights must be enforced. Criminal sanctions are often appropriate not only for counterfeiters but for a range of infringements, not least because these sanctions can be less costly to the brand owner than civil remedies. 'Criminal remedies against counterfeiting' reviews the criminal remedies available, and provides a brief update on the new regulations governing the power of HM Customs \& Excise, which were discussed in detail in the last issue of this journal.

The most successful brands have behind them, of course, the most successful products, but even the most prestigious brands can be irreparably damaged by misuse and lack of protection. 'Rolex' is an example of a brand which has been subject to such relentless counterfeiting that it has lost some of its exclusivity. Other brands such as 'Elevator' or 'Linoleum' have simply lost their identities al- 
together, and become generic terms. A cost-effective and workable strategy in the adoption, development and protection of brands is essential to maintain their exclusivity and ensure that they continue to be of greatest benefit to their proprietors.

(C) Eversheds London

\section{Sarah Hodson and Sarah Playle Special Issue Editors October 2003}

\section{Eversheds Contributors}

Lucy Alcock, Eversheds London Paul Chen, Eversheds London Hui Min Ch'ng, Eversheds London Sarah Hodson, Eversheds London George Kangis, Eversheds London Sarah Playle, Eversheds London Vicki Salmon, Eversheds London Paola Scagnelli, Eversheds London Andrew Terry, Eversheds London Natalie Ward, Eversheds London

Mayer, Brown, Rowe \& Maw Contributor

Sarah Byrt 